\title{
Kinship theory after Lévi-Strauss' Elementary Structures
}

Patrick Menget

\section{(2) OpenEdition \\ Journals}

Electronic version

URL: https://journals.openedition.org/jsa/10549

DOI: 10.4000/jsa.10549

ISSN: 1957-7842

\section{Publisher}

Société des américanistes

\section{Printed version}

Date of publication: 20 December 2008

Number of pages: 29-37

ISSN: 0037-9174

\section{Electronic reference}

Patrick Menget, "Kinship theory after Lévi-Strauss' Elementary Structures", Journal de la Société des américanistes [Online], 94-2 | 2008, Online since 10 December 2013, connection on 03 September 2022. URL: http://journals.openedition. org/jsa/10549 ; DOl: https://doi.org/10.4000/jsa. 10549 


\title{
KINSHIP THEORY AFTER LÉVI-STRAUSS'
}

\author{
ELEMENTARY STRUCTURES
}

\author{
Patrick MENGET *
}

I will first add a comment to Steve Hugh-Jones' exposition, saying that I was for three years a student of David Maybury-Lewis, in the United States, and I never agreed completely with his structural-functional view of dual organisations. But he was a very liberal and tolerant teacher, and in his seminars, always very elegantly allowed my excursus in Lévi-Straussian theory. So I wish to associate myself to the homage SALSA paid to David Maybury-Lewis a few days ago ${ }^{1}$.

I will here try to examine in a random fashion some of the more paradoxical consequences of the developments opened up by Lévi-Strauss' major work on kinship, which I think should be considered as the major 20th century work on kinship. While the British school, as Steve Hugh-Jones showed us, criticised the very limited extension of Elementary Structures, French anthropologists were for a time silent about the publication. In fact, the first major review of The Elementary Structures was actually by the Dutch anthropologist, J. P. B. Josselin de Jong, in 1952. And it was mostly about the Australian kinship systems, of which he was a specialist. This timidity of French anthropologists was, I think, due to the fact that there was a fascination for the number one theory, that is the general theory of incest prohibition and exogamy on which the philosophers ranted for a few years before anthropologists, French anthropologists I mean, started to think about it. And most of them started to think about the second theory of the Structures élémentaires, which is what the British school has called the theory of prescriptive marriage systems, which Lévi-Strauss himself called " generalised » and « restricted » exchange.

Now the main follower of the second theory of Lévi-Strauss was undoubtedly Louis Dumont, who then occupied a junior teaching position at Oxford, if I remember well, and wrote that famous article on Dravidian kinship terminology as an expression of marriage alliance (1953), a paper which was well received by Radcliffe-Brown. This is the first systematisation of the alliance theory, which is

* EPHE, 45 rue des Écoles, 75005 Paris [losonczy.menget@skynet.be].

Journal de la Société des Américanistes, 2008, 94-2, pp. 29-37. OSociété des Américanistes. 
in the right line descended from the distinction between the two main types of prescriptive marriage systems, but which has an advantage over Lévi-Strauss' model and shows the limitations of his second theory. The advantage was to systematise the notion that "alliance " was a concept that was transmitted as much as «descent » was transmitted. The obvious limitation was that a whole series of non-unilinear societies were de facto, or rather de jure, excluded from this structural possibility. Lévi-Strauss himself was very conscious of this limitation as you will see if you allow me to quote a non-published interview of LéviStrauss, that was conducted by a philosopher and myself in the seventies ${ }^{2}$ (I don't remember the exact year in which this interview was conducted). It was meant to produce a book and for some reasons I forgot the publisher never put out the book, which happens, but I still have the transcript of the questions and I will just quote a few of Lévi-Strauss' answers. His first general statement said: " within the limits of unilinear systems, I hope I put some order where there was a splendid mess » (" Dans les limites des systèmes unilinéaires, j'espère avoir mis un peu d'ordre là où il y avait du bazar »).

Of course, one has to say - and Lévi-Strauss recognized that very honestly later on -, that there had been previous structural analysis of marriage systems, especially in Eastern Indonesia by van Wouden (1968 [1935]) and the Dutch school. There had also been some structural analysis of Australian systems. Yet, indeed, the systematisation of Lévi-Strauss brought along a lot of order and created a typology of marriage systems. Now, he goes on answering a question on sociology and Durkheim. I can't remember if the question was from the philosopher or from myself, we had actually prepared them together. The question was: « aren't you contributing to divorce social anthropology from sociology in the classic Durkheimian sense? eventually restricting the study of kinship structures to mental structures?» ("Est-ce que vous n'avez pas contribué à divorcer l'ethnologie d'une sociologie? Au sens classique, au sens durkheimien? C'est-à-dire en fin de compte à restreindre l'étude des structures de la parenté à des structures mentales »). Here is Lévi-Strauss' answer in the seventies: "Yes this was in Durkheim; it's not only a matter of collective consciousness but also of solidarity. But I never was convinced of that » (" Oui, c'était déjà chez Durkheim. Il n'y a pas que la conscience collective chez lui, mais aussi la solidarité. Mais je n'ai jamais été convaincu de cela »).

Then another question: « Well, when you speak about the respective efficiency of restricted exchange and generalised exchange, aren't you opposing two Durkheimian types of solidarity? " ("Pourtant quand vous parlez de l'efficacité respective de l'échange restreint et de l'échange généralisé, on sent comme un écho de la conception durkheimienne sur la solidarité ? "). "This has been written », says Lévi-Strauss, « it has been said that the difference between mechanic and organic solidarity was congruent with restricted and generalised exchange, but this is not true at all; both of them are different modalities of mechanic solidarity. The only 
challenge that I see now ", says Lévi-Strauss, " is that of cognatic or indifferentiated systems. I think we can treat them in the same fashion and in the same spirit, not only in relation to fixed positions, but in relation to mobile and self defined positions". ("On l'a écrit. On a dit que c'était la différence entre la solidarité mécanique et la solidarité organique, mais ce n'est pas vrai du tout. Tout ça, ce sont différentes modalités de solidarité mécanique. Je suis d'accord que le grand challenge de maintenant, c'est le système indifférencié. Mais je pense qu'on arrivera à le traiter de la même façon et dans le même esprit, non pas par rapport à un repère fixe mais par rapport à des repères qui se redéfinissent eux-mêmes à chaque instant ").

Now as you know, there, the attempt to treat more non unilinear systems was systematised in a plan or a project exposed in the Huxley Memorial Lecture, where Lévi-Strauss (1965) defines the semi-complex structures, by which he means kinship terminologies in which prohibitions are multiplied and there is no formal positive marriage prescription. The terminologies which exhibit this feature in the most blatant, evident way are the Crow and Omaha terminologies and several works, the most notable of them being that of Françoise Héritier (1981), whose ethnography deals with the Samo society in Central Africa, attempted to reanalyse the Crow/Omaha logic. Without going into details, one could say that the semi-complex structures did not reveal any new systematic structure in terms of marriage prescription, in spite of the quality of Françoise Héritier's ethnography.

Now at the same time Françoise Héritier developed the other aspect of Lévi-Strauss' theory, which is the theory of incest, and she brilliantly attempted to systematise the world array of incest prohibitions. She made a fascinating and very systematic review of degrees and kinds of incest and their social, physiological and even psychological consequences. There were some difficulties however with this approach, the main difficulty, and she was criticised for that, was a tendency to reify principles of analysis of incest prohibitions, or a typology of incest prohibitions, into substances. Indeed, she made a sort of calculus of substances in as much as they were contributing to form identities: sexual identities, kinship identities. The problem is that this calculus of substances into identities is not always congruent with social mechanisms, including marriage alliance systems. Second difficulty of her theory, I believe, and this I think was pointed out by Eduardo Viveiros de Castro (1993a), among others, is that the general principle of dominance, male/female, that she postulated indeed largely verified empirically, does not always belong to the same set of principles as the substantial idiom, or as the French would say in the old days, in Rabelais's days, as the "substantifique » idiom; they indeed are often two contrasting idioms, difficult to reconcile. Just one ethnographic example from my main fieldwork among the Ikpeng of Central Brazil, a Karib-speaking group (Menget 1979). The Ikpeng claim that the sons look like their fathers, they take after their fathers and 
the daughters take after their mothers, which is quite congruent with Françoise Héritier's analysis, but then they also have a belief that is contradictory to this one, which is that the whole substance of the embryo, of the fotus, is male substance. So the question is, how do they reconcile those two beliefs? I did ask the question from the women of course and they said - and you'll see that it's another contradiction - " oh yes but you know, little girls suckle milk » and I said " but don't the boys also »? There is no way out and this of course is not enough to disqualify Françoise Héritier's work on typology of incest, but one has to recognise that the marriage system approach, the elementary structures, have not really been extended through the typology of incest that Françoise Héritier has produced.

Lévi-Strauss himself draws away from functional structural analysis and I will rephrase some of the findings of Steve Hugh-Jones right now, by simply quoting a citation from the Elementary Structures of kinship. And I think the crux of the argument between Maybury-Lewis and Lévi-Strauss was that dual organisation is not primarily an institution, as far as Lévi-Strauss is concerned. It is, indeed, a sort of mental, very general structure. The quote is from Elementary Structures and says: « if dual organisation really reaches the institutional stage, it nevertheless has to do with the same psychological and logical rules as all those sketchy or partial forms, sometimes simple outlines, which are formulations of the principle of reciprocity, for the same reason, thought not always as systematically, as dual organisation is just such a formulation. Accordingly », and this is $m y$ insistence, " dual organisation is not in the first place an institution. It is above all a principle of organisation capable of widely varying and in particular of more or less elaborated application » $(1969$, p. 75$)$. Then he gives examples: sporting rituals, political life, religious and ceremonial activity, and marriage systems. «In all these forms, there is a difference » - I'm still quoting -, " of degree, not of kind, of generality, not of type " (ibid.).

Now I will just briefly mention one of the latest analysis of origin myth in Histoire de lynx where Lévi-Strauss contrasts Tupi and Gê, showing that a fairly common Gê myth is just an inverted version of the origin myth of the Tupi. He makes an interesting point, and I will bring Dumont back. He says that you could analyse this origin myth, and some of the rituals that evoke that myth, as a series of bipartitions creating, by successive differentiation, the elements and parts of the world, of the cosmos. Now what is the most interesting element of that discussion is that he is using in fact, without ever quoting Dumont, but that's normal, a concept which is the concept of hierarchical oppositions and ever since the sixties, each time Lévi-Strauss has been analysing dual forms, or dualistic forms in general, he has been stressing the fact that these oppositions were hierarchical and even quotes somewhere his very first article on the Bororo (1936), dealing with reciprocity and hierarchy, which I think has been retaken by Christopher Crocker (1977) about 35 years later. Now it's obvious that the 
structural functionalist approach to dual organization has taken him away from prescriptive marriage systems. The example of the Bororo is interesting, because the Bororo moieties are clearly exogamic. Yet, very detailed analysis made by Zaco Levak (1971), a Yugoslav anthropologist, of the marriage system and of the actual marriage practices cannot show regularities, patterned regularities, in the marriages between the clans. In other words, the marriages are fairly random, while respecting the generic rule of exogamy. That's one of the points, I think, that South-Americanists have been making.

I will briefly mention the elaboration that Steve quoted about the dravidianate, by Eduardo Viveiros de Castro (1993b), and while it is true that this is an extension of The Elementary Structures in as much as the Dravidian terminologies come fairly common in South America and not usually accompanied by unilinear affiliation or descent, nevertheless, the extent of the symmetrical marriage itself is rather limited. That is, the multi bilateral marriage system that Eduardo Viveiros de Castro invented, is indeed a way of dispersing alliance but does not create any chain or cycle of permanent functional structure.

I will now come back to more recent works because we had reached a point, in the late eighties, when there were no major extensions of The Elementary Structures. There was a kind of impasse in the analysis of semi-complex structures and it was a time when endogamous forms of marriage were more and more a thorn in the flank of French anthropologists. These forms of marriage, the most famous of them being the so-called Arabic marriage, which actually is not specifically Arabic but extends from Western Africa to Pakistan, maybe. This form exhibits regularities and one has the intuition that they are a system, even though it has not been proven, and even though Lévi-Strauss himself has been one of the critiques of the formal interpretation by Kasdan and other people (Murphy and Kasdan 1959), disqualifying them as purely functional and extremely weak. Both Bourdieu (Bourdieu and Sayad 1972) and Lévi-Strauss criticised the functional interpretation of this marriage.

Now, I will quote a former student of mine who has just published a book called La Parenté, Laurent Barry (2008), who retakes a very interesting remark of the second edition of Les Structures élémentaires (1967) where Lévi-Strauss says, in answer to Needham (1962) and Leach (1965), « the point is not to quibble about prescriptive or preferential. The point is that each time you have a prescription that's linked to a prohibition, you have an elementary structure. Now if you don't have a positive prescription, you ought to look for the practice, the empirical practice, of the marriages $»$. Now Laurent Barry made a very interesting point, and this is strictly after Lévi-Strauss (1967/1969), he said « Well in endogamous marriage, we do have a prescription, but what is the prohibition $»$ ? And he started examining both the empirical implications of this famous bint'amm marriage (father's brother's daughter in Arabic), that has become to be called " the Arabic marriage » and also the prohibitions that are numerous and 
looked rather irrational, the most famous being the milk nurse prohibition. And he showed that if you systematically consider both the empirical application, the so-called prohibitions that do not look systematic because they are on the maternal side whereas as we all know the Arabic societies adhere to strong unilineal agnatic principles, there is a system that starts emerging from this endogamous form. In a very Lévi-Straussian manner, but steering away from the marriage-exchange models, Laurent Barry makes the point that the essence of kinship is not descent, or marriage, or alliance rather, but it's a sort of « je ne sais quoi » that is being transmitted. Laurent Barry I think is on the right track saying that there is a " je ne sais quoi » (he doesn't really define it, except as « a common ontological identity, a form of consubstantiality ", 2008, p. 168) that is being transmitted. And that's the essence of kinship, as distinct from the rights and duties, and material and spiritual things, that unilateral and sometimes bilateral systems transmit. So this " whatever », this " je ne sais quoi » avoids him from reifying substantific principles just like Françoise Héritier did, sometimes, and puts the emphasis on whatever is transmitted. Now British social anthropologists would tell us: « Now this is complementary filiation, my boy... » [laughs]. Well, it is and it is not, and I think there is an interesting yield of this perspective, of Laurent Barry's perspective, in his analysis of Arabic marriage. He further takes the symmetric figure of the Chinese, the Han marriage, that is a marriage with the mother's sister's daughter, where both the ethnographic data are scantier and the analysis is less elaborate than for the Arabic marriage, but it's an interesting attempt. There again, as in his study of the Arabic marriage, a combination of marriage prohibitions (here on the father's side), never systematically considered, and of significant statistics of "preferred » (rather than strictly prescribed) marriages reveals a system, based on the same hypothesis of transmission of a quality distinct from descent or filiation, in a highly patrilineal context. Now the questions that he raises, of course, suscitate a new problem, because whatever is being transmitted is, for an ego, what he calls a group-membership. Now, the difliculty therein is that ego-centred configurations vary with each ego. We all know from classic theory that two brothers in a cognatic system may not have the same category of kin. So one wonders what kind of group can be defined in this perspective. Yet, I would like to insist on the fact that it breaks away with the strong, almost mythical, logical correlation between incest and exogamy. That is, incest has to do with kinship in this sense of transmitting quality, or " whatever » quality, but does not necessarily lead to an exogamic marriage system. Prohibition of incest and exogamy ought to be considered separately and I think that the extension of systems in kinship and marriage, kinship and alliance, as the British would say, will benefit from this renewed interpretation of the Structures. Thus, when the functionalist residues of Lévi-Strauss' theory of exchange have been set aside, and Lévi-Strauss himself contributed to this, it appears that the structural method has permitted to extend the consideration of marriage systems much 
beyond the restricted and generalised standard forms, and more generally outside the framework of the exchange theory.

Reverting to the global level of the dualistic structures, as exemplified by the superb finale of Histoire de lynx, some of the most interesting myth analysis recently produced have followed this lead and I am glad that Steve Hugh-Jones alluded to Peter Gow's recent work, An Amazonian myth and its history (2001). Dualistic structures are thus a more general pattern, even a mental or cognitive one, than the institution that has been categorized as an exogamous marriage system. As a brief conclusion, let me say that Lévi-Strauss' theory of kinship has been developed first in expanding the range and scope of marriage systems, through giving up, or rather suspending, the strict exchange principle among groups, but also by analysing dualistic structures as more general properties of human cognition, of which social structures are but a cas particulier:

Thank you.

\section{NOTES}

1. On Thursday June 19th, two days before this paper was read, Salsa had organised a tribute to Maybury-Lewis (1929-2007), held at the Pitt-Rivers Museum at Oxford.

2. Editor's note: we had initially considered publishing selected extracts of this interview. However, Claude Lévi-Strauss objected to this publication, putting forward that his great age and failing health wouldn't allow him to revise it.

\section{REFERENCES}

BARRY Laurent

2008 La parenté, Gallimard, Folio Essais, Paris.

Bourdieu Pierre and Abdelmalek SAYAD

1972 "Stratégie et rituel dans le mariage kabyle », in John G. Peristiany (ed.), Mediterranean family structures, Cambridge University Press, Cambridge [English translation: 1977, Outline of a Theory of Practice, Cambridge University Press, Cambridge].

Crocker Christopher

1977 "The mirrored self: identity and ritual inversion among the Eastern Bororo ", Ethmology, 16 (2), pp. 129-145.

Dumont Louis

1953 " The Dravidian kinship terminology as an expression of marriage », Man, 54, pp. 34-39.

Gow Peter

2001

An Amazonian myth and its history, Oxford University Press, coll. « Oxford studies in social and cultural anthropology ", Oxford. 
HÉRITIER Françoise

1981 L'Exercice de la parenté, Le Seuil-Gallimard, Paris.

HÉRITIER-AugÉ Françoise et Elizabeth COPET-ROUGIER

1993 "Commentaires sur commentaire. Réponse à E. Viveiros de Castro », L'Homme, 125, 33 (1), pp. 139-148.

JoSSELIN DE JONG J. P. B.

1952 Lévi-Strauss's theory on kinship and marriage, Brill, Mededlingen van het Rijksmuseum voor Volkenkunde, 10, Leiden.

\section{LeACH Edmund}

1965 "Claude Lévi-Strauss. Anthropologist and Philosopher », The New Left Review, 34, p. 20.

LevaK Zarko David

1971 Kinship system and social structure of the Bororo of Pobojari, Ph.D. dissertation, Yale University.

Lévi-Strauss Claude

1936 "Contribution à l'étude de l'organisation sociale des Indiens Bororo ", Journal de la Société des américanistes, 28 (2), pp. 269-304.

1965 "The future of kinship studies. The Huxley Memorial Lecture 1965 », Proceedings of the Royal Anthropological institute of Great Britain and Ireland, pp. 13-22.

1967 Les structures élémentaires de la parenté, Mouton/Maison des Sciences de l'Homme, La Haye/Paris [1949].

1969 The Elementary Structures of kinship, Beacon Press, Boston.

Menget Patrick

1979 "Temps de naître, temps d'être: la couvade », in Michel Izard and Pierre Smith (eds), La fonction symbolique : essais d'anthropologie, Gallimard, Paris [English version: 1982, " time of birth, time of being: the couvade ", in Michel Izard and Pierre Smith (eds), Between belief and transgression: structuralist essays in religion, history and mythology, University of Chicago Press, Chicago, pp. 193-209].

MURPhy Robert F. and Léonard KASDAN

1959 "The structure of parallel cousin marriage », American Anthropologist, 61, pp. 17-29.

NeEDHAM Rodney

1962 Structure and sentiment, The University of Chicago Press, Chicago.

Viveiros de CASTro Eduardo

1993a "Structures, régimes, stratégies », L'Homme, 125, 33 (1), pp. 117-137.

1993b "Alguns aspectos da afinidade no dravidianato Amazônico », in Eduardo Viveiros de Castro and Manuela Carneiro da Cunha (eds), Amazônia: etnologia e historia indigena, USP/FAPESP, São Paulo, pp. 150-210. 
WOUDEN F. A. E. van

1968

Types of social structure in Eastern Indonesia, Martinus Nijhoff Koninklijk Instituut voor Taal-, Land- en Volkenkunde, Translation Series 11, The Hague [1935]. 